The Effect of Analyst's Earning Forecasts on their Stock Recommendations

Dr/ Samar Mansour Elsebaai Mohamed

\title{
The Effect of Analyst's Earning Forecasts on their Stock Recommendations
}

\section{Samar Mansour Elsebaai Mohamed Moubarak}

\begin{abstract}
:
This study use a sample which consists of 88 observations of Egyptian listed firms, from the period of 2009 - 2019. This research investigates the role of financial analysts which is helping investors to make stock investment decisions by issuing earnings forecasts and stock recommendations to the market. Users of earnings forecast reports will make their own subjective evaluations about the validity and importance of such reports; these evaluations can determine the degree to which the users will trust in, and adopt, the reports' recommendations when they make investment decisions. Finally findings revealed positive relationship between forecast accuracy and recommendations as financial analysts serve as information intermediaries by providing reports that include earnings forecasts and their stock recommendations. These recommendations help investors to make their decisions.
\end{abstract}

Keywords: analysts' earnings forecasts; buy side analysts; sell side analysts; stock recommendations.

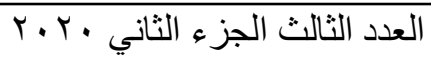

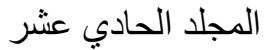


The Effect of Analyst's Earning Forecasts on their Stock Recommendations

Dr/ Samar Mansour Elsebaai Mohamed

\section{1- Introduction and the research problem:}

In recent decades, there are many developments on the economic, social or political level .The owners of companies realize the importance of accounting from just being bookkeeping and record data to become a tool to deliver information about the actual and real situation of the company to the interested parties especially investors. Financial analysts have a pivotal role in reducing the information asymmetry between enterprise management and external market participants in the external market to support market efficiency. Also the forecasts of analysts serve as expectations of a firm's prospects in the future they play a key role in promoting value of the firm.

Financial analysts are gathering firm information about business entities to issue their reports. They also issue earnings forecast and recommendations on given securities published to benefit and for the use of the customers for their firm. To establish better career path analysts need to attract attention of investors and enhance their reputation. Earnings forecasts are considered to provide investment sector with valuable information. Evaluating a firm's potential investment opportunities is critical to investors to determine the intrinsic value of a firm and to design effective managers' compensation contracts for boards of directors.

$$
\text { العدد الثالث الجزء الثاني • r r r }
$$$$
\text { المجلد الحادي عشر }
$$ 
The Effect of Analyst's Earning Forecasts on their Stock Recommendations

Dr/ Samar Mansour Elsebaai Mohamed

Earnings forecasts need to be informative to be valuable before to the release of earnings reports. Accurate and informative earnings forecasts promote managers credibility and enhance analysts' reputation in financial markets, and help analysts attaining higher annual compensation and better career prospects.

Many accounting research has focused on earnings forecast's attributes of financial analysts, but less attention has been given to the importance of earnings forecasts which help investors to select stock. so the other part of this study show how analysts' earnings forecasts make their stock recommendations, this means that stock recommendations can be affected by some characteristics such as managerial ownership.

\section{2- Literature Review and Hypothesis Development:}

This part reviews the previous study including the relationship between equity incentives and analysts stock recommendations. Stock recommendations are issued by financial analysts after making their analysis which takes different forms. These recommendations illustrate and summarize their opinion about the intrinsic value of a firm compared to the value of the stock market. There are different factors that affect stock recommendations.

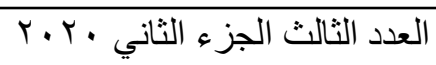

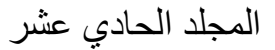


The Effect of Analyst's Earning Forecasts on their Stock Recommendations

Dr/ Samar Mansour Elsebaai Mohamed

In the same context some other previous studies such as (Akono, et al., 2019) Analyst rounding of EPS forecasts and stock recommendations. Advances in Accounting suggested that there is significant association between the quality of earnings forecasts and their stock recommendations. Recently forecast accuracy is considered very important issue for investors. The financial analysts are one of the key users of financial statements; they collect historical earnings information and use it in their forecasting process. Next, they investigates the impact of Regulation Fair Disclosure and the Global Research Analysts Settlement) on the association between earnings forecasts process and stock recommendations. This study tests analysts predictions that they made by their relations with management. Consequently, analysts will be willing to provide structured earnings forecasts in accordance to unfavorable stock recommendations (underperform or sell). Findings Use sample of 53,582 analyst-firm-year observations, results reveal that analysts seem to provide structured earnings forecasts in accordance with unfavorable stock recommendations prior to Reg FD.

Also they found that prior to Regulation Fair Disclosure, analysts provide earning per share forecasts in accordance with unfavorable (underperform and sell) recommendations. However, after Reg FD, they found no significant relationship between earnings forecasts and unfavorable stock recommendations.

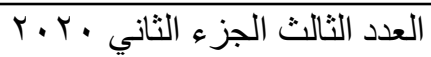

المجلد الحادي عشر 
The Effect of Analyst's Earning Forecasts on their Stock Recommendations

Dr/ Samar Mansour Elsebaai Mohamed

(Kim, et al., 2020) The optimism and accuracy of bankaffiliated analysts' forecasts they investigate the impact of information flows within banking groups on analysts' forecasts and on the financial markets.

Findings show that earnings forecasts for bank-affiliated analysts are less optimistic and more accurate than independent analysts. Capital market recognizes that independent companies rely on the bank-affiliated analysts' recommendation changes; this means that these recommendations are more reliable. Findings also provide evidence that banking system add benefits in emerging markets by providing better research reports for nonbusiness-group-affiliated companies and exchange the information generated by commercial banks.

\section{Also (Pan and Xu, 2019) The association of analysts' cash} flow forecasts with stock recommendation profitability investigate how the stock recommendations profitability can be affected by analysts' cash flow forecasts and if the positive effect of cash flows forecasts on analysts' stock recommendation performance differ according to earning quality. Results show that when analysts issue cash flow forecasts, their stock recommendations achieve higher profitability. In addition, they indicate the positive association between cash flow forecasts and recommendations profitability is stronger for firms with low earnings quality than for firms with high earnings quality. Their

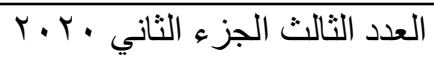

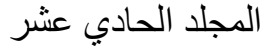


The Effect of Analyst's Earning Forecasts on their Stock Recommendations

Dr/ Samar Mansour Elsebaai Mohamed

findings indicate that cash flow forecasts play a more important role in firm valuation issued by analysts according to market demand likely than cash flow forecasts issued by analysts.

\section{Additionally (Ishigami and Takeda, 2018) Market} reactions to stock rating and target price changes in analyst reports: Evidence from Japan they using a large number of analyst reports to investigate a detailed analysis about the effects of both stock ratings and target prices that issued by analysts to investors in the stock markets. In addition to the impact of stock rating changes on its prices. They analyze the combined effects of stock ratings and target prices. Moreover, results found that market responses are affected by the quality of information in the analysts' reports and the number of analyst's reports issued on the same day.

\section{Additionally (Premti, et al, 2017) Information content of} analyst recommendations in the banking industry identifies the usefulness of analyst recommendations in in times of uncertainty of the information environment. The degree of uncertainty in the information environment varying because of variances in information asymmetry and in regulations across the periods. The sample used in this study consists of 23,632 analyst recommendations; they found that analyst recommendations in banks that are risky and have high level of information asymmetry are more valuable and informative. Results found in

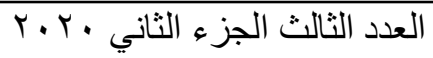

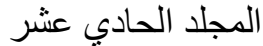


The Effect of Analyst's Earning Forecasts on their Stock Recommendations

Dr/ Samar Mansour Elsebaai Mohamed

the bank institutions the information content of analyst recommendations is increased due to rules and regulations (Sarbanes-Oxley Act) and decreased due to the risk (Dodd- Frank Act). Those results ensure the valuable role of an analyst during uncertainty of the information environment.

\section{(Barniv et al., 2010) International Evidence on Analyst} Stock Recommendations, Valuations, and Returns investigate the straightforward association between analysts' earnings forecasts and their stock recommendations. Analysts form their predictions about future earnings of the company (present value of future cash flows) to evaluate its intrinsic value. Analysts use residual income valuation model to form their earnings forecasts. Results found residual income predictions in countries with high number of investors have negative effect on stock recommendations. In contrast, in companies with low number of investor's, there are negative association between residual income values and stock recommendations. Findings also reveal when the estimated residual income value is more than the current stock price, analysts issue a buy recommendation and when it less than stock price, recommendations will be sell.

There are other researches that examine how investor's capabilities vary according to process information and their response to new information even optimistic or pessimistic.

$$
\text { العدد الثالث الجزء الثاني • r. r }
$$

المجلد الحادي عشر 
The Effect of Analyst's Earning Forecasts on their Stock Recommendations

Dr/ Samar Mansour Elsebaai Mohamed

Considering the properties of analyst forecasts, prior research has focused on accuracy, bias (optimism) and dispersion (Brown, et al., 2016) divides the analysts who are the essential input to form stock recommendations into buy side and sell side analysts. The buy-side analysts are those worked for institutional investors to enable those making decisions, but the sell-side analysts are considered to be the providers of the earnings forecasts, operating for the favor of brokerage institutions and individual investors. In addition the two broad aspects of research on analyst estimations are the features of consensus analysts' forecasts and individual analyst forecasts.

Unlike sell-side analysts who can be widely spread their stock recommendations and to their users, Buy-side analysts suggest that private connection with top executive management is significant input into their stock recommendations. In addition, sell-side analysts play vital role in promoting managerial access. Buy side analysts investment recommendations are not open to those outside their own company

\section{Also (Keske, and Tse, 2016) Does Forecast Bias Affect} Financial Analysts' Market Influence? Examine how the market affected with forecast Bias. In poor information environments analysts attempt to bias their estimations upwards and in rich information environments downward.

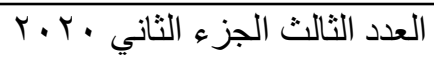

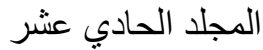


The Effect of Analyst's Earning Forecasts on their Stock Recommendations

Dr/ Samar Mansour Elsebaai Mohamed

From this context the study of (Lustgarten and Tan, 2016) Analysts' Heterogeneous Earnings Forecasts and Stock Recommendations. Investigate whether the analysts make their recommendations based on their earnings forecasts, when analysts' earnings forecasts are more optimistic, their recommendations will be more favorable. Findings indicate there is strong relationship between recommendations and forecasts analysts when the value of earnings is relevant. Results show some factors that make stock recommendations more responsive to earnings forecasts. These factors such as lower earnings volatility, high growth, low market risk, healthier financial conditions, and larger analyst following). Results show that when analysts forecast revision becomes more positive, this motivate analyst to issue a buy recommendation. Also the relationship between earning and stock recommendations positive when the earning is timeliness.

In the similar context (Yezegel, 2015) Why do analysts revise their stock recommendations after earnings announcements?. Illustrates the importance of sell-side analysts as they provide valuable information to their clients through their recommendations. Analysts should revise their recommendations when there is a larger earnings surprise as investors pay to access analysts' research reports. Findings show that greater demand from investors motivate analysts to issue recommendations. So

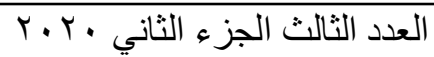

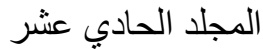


The Effect of Analyst's Earning Forecasts on their Stock Recommendations

Dr/ Samar Mansour Elsebaai Mohamed

they provide useful recommendations after earnings announcements achieve the desire of investors.

Also the study of (Hobbs and Singh, 2015) A comparison of buy-side and sell-side analysts. This study compared between buy-side and sell-side analysts through analyzing the activities of analyst to investigate and analyze the behavior of buy-side and sell-side analysts and the portfolios performance that depend on their recommendations. Their Finding shows that:

1- Low performance of sell-side recommendations affect the return to portfolios to be positive, and the returns of buy side analysts are negative.

2- Low performance of Buy-side analysts' occurs when they trade against sell-side analysts' recommendations.

3- Some factors such as the portfolio size and the portfolio turnover of buy-side analysts' institutions have positive effect on abnormal returns, so large companies employ superior analysts.

4- Buy-side portfolios with stocks that have higher analyst coverage, greater institutional holding, and lower earnings forecast dispersion have positive impact on abnormal returns.

For example (Chen et al, 2017) The Confirmation Effect of Analyst Recommendation Reiterations. Examine Favorable compared to Unfavorable Recommendations, and how forecast

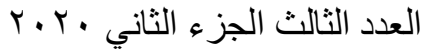

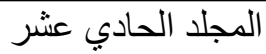


The Effect of Analyst's Earning Forecasts on their Stock Recommendations

Dr/ Samar Mansour Elsebaai Mohamed

accuracy of analysts affect on recommendation to increase or decrease issuance under the assumption management-provided information will increase or decrease. Findings show that analysts with more experience provide more favorable recommendations. Also results show that the greater increase in relative accuracy for analysts with more favorable recommendations exists before implanting the regulations. Also when management offer more information, this enable analysts to make more favorable recommendations.

Also (Vukovic, et al, 2020) Analyst says a lot, but should you listen? Evidence from Russia found that investors in the stock market highly respond to analyst recommendations publications. They investigate the effect of other factors that affect on the market when an analyst's recommendations are published such as (recommendation levels changes, size of the company and 1 economic position). The analysis form three types of recommendations: "buy," "hold" and "sell." Findings of this study ensure that the market responds to other factors besides separate forecasts.

The research gab in this study can be summarized as: This part of study offer investors how analysts' earnings forecasts make this stock recommendations means both of ownership and control characteristics such as managerial ownership consider as input that help to issue stock recommendations. There is straight forward relation between analysts' earnings forecasts and their

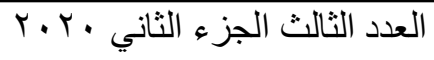

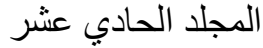


The Effect of Analyst's Earning Forecasts on their Stock Recommendations

Dr/ Samar Mansour Elsebaai Mohamed

stock recommendations to be optimistic or pessimistic. Financial analysts in companies with high level of management compensation can issue and provide favorable stock recommendations for in the form of equity based compensation. Analyst's recommendation in the financial market to buy or sell a stock is considered an estimation that helps to predict the stock return in the future.

\section{3- The Research Method:}

Research methods are the strategies, processes or techniques utilized in the collection of data or evidence for analysis in order to uncover new information or create better understanding of a topic. There are different types of research methods which use different tools for data collection: quantitative, qualitative and mixed methods (Igwenagu, 2016).This study use qualitative research as Inductive research methods are used to analyze the observed phenomenon whereas, deductive methods are used to verify the observed phenomenon. Inductive approaches are associated with qualitative research and deductive methods are more commonly associated with quantitative research.

\section{Statistical Analysis Used}

The researcher will conduct descriptive analysis including minimum, maximum, mean, median and standard deviation for the variables of the study.

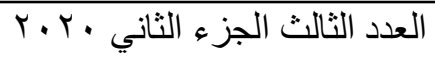

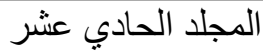


The Effect of Analyst's Earning Forecasts on their Stock Recommendations

Dr/ Samar Mansour Elsebaai Mohamed

\subsection{Sample Construction}

The researcher will make analysis of financial reports for the international firms. The researcher starts my sample construction by selecting top international and multinational companies from the year 2009 to 2019 .

\subsection{Data Sources}

This study uses Egyptian listed companies during 2009 to 2019 as analysis sample. Sample is international and multinational companies that have data used in this study. Some financial and accounting information data are extracted from the Egyptian Stock Market, Accounting Research database and Egypt for Information Dissemination (EGID).

\section{Specification of the Research Model}

\subsection{Variables Measurements:}

This section describes the variables of the model including dependent, independent, and control variables. Multiple regression models are employed to examine the impact of Equity incentive plans on the accuracy of analysts' earnings forecasts. .

\subsection{1 independent Variable}

(a) The accuracy of analyst's earnings forecasts

The dependent variable is the accuracy of analyst's earnings forecasts. The researcher follow the model (Kanagaretnam , et al., 2012) to measure forecast accuracy, which can be measured

$$
\text { المجلد الحادي عشر }
$$


The Effect of Analyst's Earning Forecasts on their Stock Recommendations

Dr/ Samar Mansour Elsebaai Mohamed

as minus one times the absolute value of the deviation of the mean EPS forecast from the actual EPS for that year divided by stock price at the forecast date. This measure increases with forecast accuracy.

$$
\text { ACCURACYit }=(-1) * \frac{\mid \text { FEPS }}{\left.\frac{\mathrm{I}, \mathrm{t}-1}{\mathrm{P}_{\mathrm{i}, \mathrm{t}-1}}-\text { AEPS }_{\mathrm{i}, \mathrm{t}-1}\right\rfloor}
$$

where, for firm i, ACCURACYt is minus one times the absolute forecast error at time $\mathrm{t}$, FEPS $\mathrm{t} \mathrm{t}-1$ the mean EPS forecast from Egyptian companies for year $t$ made at time $t$ 1, AEPSt is the actual earnings per share and Pt-1 is the stock price at a specific date.

The researcher also can measure the accuracy of earnings forecasts by calculating absolute forecast error (Bias). Bias is the deviation degree of analysts' earnings forecasts. In order to measure the accuracy of earnings forecasts, the researcher use the deviation degree of analysts' earnings forecasts, which is calculated as the following Equation

$$
\text { Bias }=\frac{\text { FEPS }_{\mathrm{i}, \mathrm{t}-1}-\text { AEPS }_{\mathrm{i}, \mathrm{t}-1}}{\text { FEPS }_{\mathrm{i}, \mathrm{t}}}
$$

$F E P S_{\mathrm{I}} \mathrm{t}-1=$ the mean earnings per share (EPS) forecast one year ahead for year

$A E P S_{\mathrm{I}, \mathrm{t}} \mathrm{t}=$ the actual EPS for year $\mathrm{t}$;

$F E P S_{I}, t=$ forecasted earnings per share for the year $\mathrm{t}$.

العدد الثالث الجزء الثاني • r.

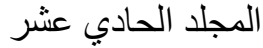


The Effect of Analyst's Earning Forecasts on their Stock Recommendations

Dr/ Samar Mansour Elsebaai Mohamed

Lower value in Bias means that there is lower level of errors in analysts' earnings forecasts, which means the higher analysts' earnings forecasts accuracy.

Analysts are evaluated based on multiple criteria such as stock picking ability, earnings forecast accuracy, quality of written reports, and overall service methodology adopts a firm-year perspective. For each firm-year. The researcher sort analysts into quintiles based on the accuracy of their forecasts of annual earnings.

Also According to the study of (Hall and Tacon, 2010) analysts covering each firm are ranked according to absolute forecast error. Analysts with relatively low forecast error are labeled "most accurate", analysts with relatively high forecast error are labeled "least accurate" and the mid-ranked analysts are labeled "moderate".

Specifically, with respect to 1 year ahead forecast accuracy, analysts with absolute forecast error below the 49th percentile are most accurate, analysts above the 51st percentile are the least accurate and analysts from the 49th to 51st percentiles have moderate accuracy.

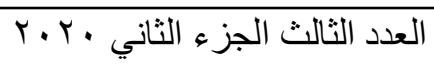

المجلد الحادي عشر 
The Effect of Analyst's Earning Forecasts on their Stock Recommendations

Dr/ Samar Mansour Elsebaai Mohamed

\subsection{2 dependent variable}

\section{Analyst's stock recommendations}

According to prior studies such as (Brawn, et al, 2016; Ismhigami and tekeda. 2018; Simon and Curtis, 2011) which indicate positive and direct relationship between analysts forecast accuracy and their stock recommendations.

The researcher determine if the forecast accuracy is high the recommendation will be buy, if the accuracy is moderate the recommendation will be hold, and if the accuracy is low the recommendation will be sell.

\subsection{Data analysis and Results:}

In an effort to test hypothesis, the results of previous studies (Brawn, et al, 2016; Ismhigami and tekeda. 2018; Simon and Curtis, 2011) show that there is positive association between analyst's accuracy and their stock recommendations.

Therefore ,The Researcher in this study explain Stock recommendations issued by security analysts, analysts are sorted according to their relative earnings forecasting ability for each firm that they cover that means analyst's use the information in their earnings forecasts in generating stock recommendations. This study investigates how an analyst's initial precision in forecasting earnings may affect their ability to issue profitable recommendations.

$$
\text { العدد الثالث الجزء الثاني • r. r }
$$

المجلد الحادي عشر 
The Effect of Analyst's Earning Forecasts on their Stock Recommendations

Dr/ Samar Mansour Elsebaai Mohamed

Besides, the researcher has used percentages that express accuracy of earning forecast. Specifically, According to (Hall and Tacon, 2010) Bias is the deviation degree of analysts' earnings forecasts. In order to measure the accuracy of earnings forecasts, the researcher use the deviation degree of analysts' earnings forecasts. This means the accuracy is high when the BIAS ratio is less than $49 \%$ which express high level of accuracy and in this case the analyst recommend to buy stock, while if this percentage falls between $49: 51 \%$, this indicates that accuracy is moderate in a way that make analysts recommend to hold shares . While If the BIAS ratio is greater than $51 \%$, this means that the accuracy is low, in this case analyst recommend to sell stock .

Last, if the recommendation is buy, this means a recommendation to purchase a specific stock. This implies that analysts expect the price of a stock to move higher in the shortto mid-term. While if recommendation is sell, this means that analysts project the price of a stock will fall below its current level in the short- to mid-term. It also implies that analysts have identified major challenges that exist at a company.

While the recommendation is hold, when an analyst expect it to perform in-line with the market and at the same pace as similar stocks. This technically tells stock brokers not to sell a stock nor buy more of it. A hold rating is often assigned when there is uncertainty in a company regarding new products/services

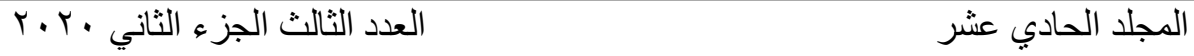


The Effect of Analyst's Earning Forecasts on their Stock Recommendations

Dr/ Samar Mansour Elsebaai Mohamed

Findings and results that reveal on the relationship between the accuracy of earning forecast and stock recommendations in companies with high level of equity compensation are shown in the following table

Table (1)

stock recommendations according to analysts forecast accuracy

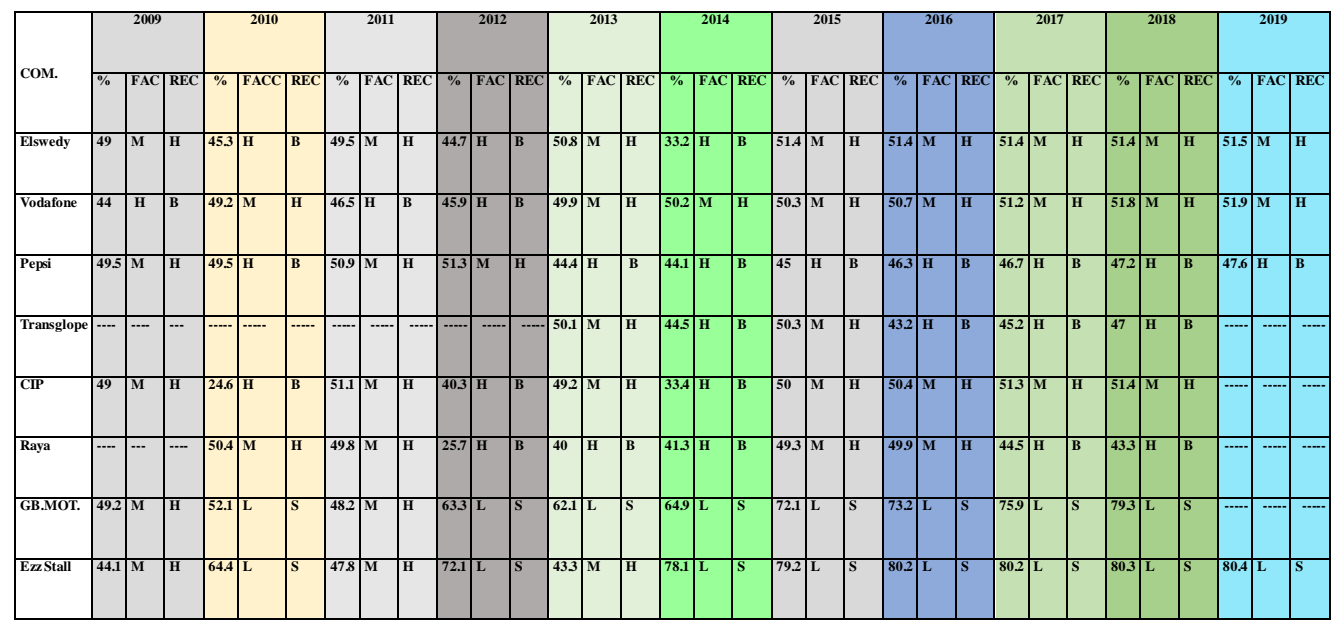

*FACC. means accuracy of earning forecast , REC means Recommendations in companies with high level of equity compensation , * Accuracy of Earning Forecast ( H--- High , M--- moderate , L---- Low) .

* Recommendations ( B ---- Buy , H--- Hold , S --- Sell ) . 
The Effect of Analyst's Earning Forecasts on their Stock Recommendations

Dr/ Samar Mansour Elsebaai Mohamed

\section{Summary and Conclusions :}

This chapter provides a summary of my dissertation; it includes the results of the applied study and then discusses the contributions compared to prior study, as well as provides directions for future research.

\section{Summary and discussion}

Finally, results of an examination of the research hypothesis, show that there is positive association between analyst's accuracy and their stock recommendations as financial analysts are more likely to issue stock recommendations after making their analysis which take different forms buy, hold, sell). This results matching with prior studies such as (Brawn, et al, 2016; Ismhigami and tekeda. 2018; Simon and Curtis, 2011).

Results in this study indicate that if the forecast accuracy is high the recommendation will be buy, if the accuracy is moderate the recommendation will be hold, and if the accuracy is low the recommendation will be sell. This means that financial analysts play an important role in the capital markets, gathering and processing information about a firm and issuing recommendations and forecasts to investors.

Bias refers to the percentage difference between realized EPS and forecast EPS, and measures analysts earning's accuracy and

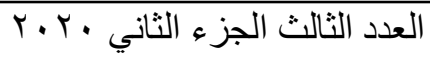

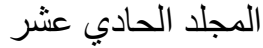


The Effect of Analyst's Earning Forecasts on their Stock Recommendations

Dr/ Samar Mansour Elsebaai Mohamed

analyst optimism or pessimism. Analysts face to bias their forecasts optimistically; First, analysts optimistically bias their forecasts or recommendations to satisfy current customers or to attract new investment business or to ensure access to firm's private information or for increasing their firm's trading commissions.

Financial analysts are more likely to issue stock recommendations after making their analysis which take different forms strong buy, buy, hold, sell, strong sell. They also convey valuable information to investors and have an immediate effect on stock prices. The information content of analyst recommendations depends on the analyst's skills and characteristics, such as Analyst Experience, reputation, or affiliation.

The researcher suggest further research can be made in making comparisons between Egypt and other countries and pinpoint how the International Accounting standards differs in the estimation of earning forecasts and its effect on their stock recommendations .

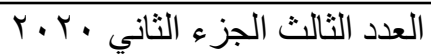

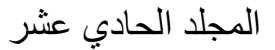


The Effect of Analyst's Earning Forecasts on their Stock Recommendations

Dr/ Samar Mansour Elsebaai Mohamed

\section{REFERENCES}

1. Akono, H., et al., (2019). Analyst rounding of EPS forecasts and stock recommendations. Advances in Accounting 44, pp.68-80.

2. Barniv., R., et al., (2010).International Evidence on Analyst Stock Recommendations, Valuations, and Returns. Contemporary Accounting Research, Vol. 27, No. 4, pp. 1131-1167.

3. Brown, L., et al., (2016). The activities of buy-side analysts and the determinants of their stock recommendations. Journal of Accounting and Economics. 62 , pp.139-156.

4. Chen, J., et al., (2017). The Confirmation Effect of Analyst Recommendation Reiterations. Journal of Accounting, Auditing \& Finance, Vol. 32(4) 576-592.

5. Hall, J., and Tacon, P., (2010). Forecast accuracy and stock recommendations. Journal of Contemporary Accounting \& Economics, vol. 6, PP.18-33

6. Ishigami, S., and Takeda, F., (2018). Market reactions to stock rating and target price changes in analyst reports: Evidence from Japan. Journal of International Financial Markets, Institutions \& Money, vol.52, PP.134-151.

7. Keskek, S., and Tse, S., (2016). Does Forecast Bias Affect Financial Analysts' Market Influence?. Journal of Accounting, Auditing \& Finance, PP.1-23

8. Kim, H., et al., (2020). The optimism and accuracy of bankaffiliated analysts' forecasts. Spanish Journal of Finance and Accounting, pp.1-23.

9. Lustgarten, S., and Tang., C.,(2016). Analysts' Heterogeneous Earnings Forecasts and Stock Recommendations. Journal of Accounting, Auditing \& Finance, PP.377-401. 
The Effect of Analyst's Earning Forecasts on their Stock Recommendations

Dr/ Samar Mansour Elsebaai Mohamed

10. Pan, S., and Xu, Z., (2019). The association of analysts' cash flow forecasts with stock recommendation profitability. International Journal of Accounting \& Information Management, PP1-19.

11. Premti, A., et al., (2017). Information content of analyst recommendations in the banking industry. International Review of Financial Analysis, vol. 49, 35-47.

12. Simon, A., and Curtism T., (2012).The Use of Earnings Forecasts in Stock Recommendations: Are Accurate Analysts More Consistent?. Journal of Business Finance \& Accounting, 38(1) \& (2), 119-144,

13. Vukovic, D., et al., (2020). Analyst says a lot, but should you listen? Evidence from Russia. Journal of Economic Studies, pp1-17.

14.Yezegel, Y., (2015). Why do analysts revise their stock recommendations after earnings announcements?. Journal of Accounting and Economics, vol.59,pp.163-1.

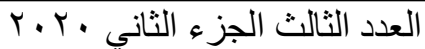

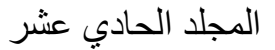

